\title{
TRINEXAPAC-ETHYL AS CHEMICAL RIPENING AGENT ON SWEET SORGHUM CROP
}

\author{
RONALDO SILVA VIANA ${ }^{1}$, BRUNO RAFAEL DE ALMEIDA MOREIRA ${ }^{1}$, \\ CELSO TADAO MIASAKI ${ }^{1}$, GUSTAVO PAVAN MATHEUS ${ }^{2}$ e ANDRÉ MAY ${ }^{3}$
}

\author{
${ }^{1}$ São Paulo State University (Unesp), College of Agricultural and Technological Science, Dracena, São Paulo, Brazil, \\ ronaldodsv@hotmail.com,bruno_rafael.m05@hotmail.com,celso.t.miasaki@unesp.br \\ ${ }^{2}$ São Paulo Agency for Research on Agribusiness Technology (APTA), Andradina, São Paulo, Brazil, gpmateus@apta.sp.gov.br \\ ${ }^{3}$ Brazilian Agricultural Research Corporation (Embrapa Meio Ambiente), Jaguariúna, São Paulo, Brazil, andre.may@embrapa.br
}

Revista Brasileira de Milho e Sorgo, v.18, n.2, p. 221-233, 2019

\begin{abstract}
Literary references on the quality of juice of sweet sorghum crop following chemical ripening agents spraying are rarely found up, mostly concerning to the trinexapac-ethyl. Accordingly, this article shares an unpublished content about chemically-induced physiological ripening on the sweet sorghum cv. CMSXS-646 by spraying trinexapac-ethyl before the crop flowering. $\mathrm{A} \mathrm{CO}_{2}$-pressurized backpack sprayer, with flat spray nozzles, was employed to exogenously spray the plant growth inhibitor at $0.4,0.8$ and $1.61 \mathrm{ha}^{-1}$ on 90 -days-old plants. Early after the crop harvesting, juice and lignocellulose samples were technologically assessed to total soluble solids, sucrose, purity, reducing sugars, total reducing sugars, fibers and yield of sugar. Sweet sorghum plants exposured to the trinexapacethyl at 0.4 and $0.81 \mathrm{ha}^{-1}$ produced juices with approximately 20.2 and $20.3{ }^{\circ} \mathrm{Brix}, 15.1$ and $13.2 \%$ sucrose, 74.6 and $64.9 \%$ purity, as well as 107.7 and $98.2 \mathrm{~kg} \mathrm{t}^{-1}$ sugar, respectively. Unlike, plants cultivated as control, juices with 21.0 ${ }^{\circ}$ Brix, $16.0 \%$ sucrose, $76.9 \%$ purity and $118.0 \mathrm{~kg} \mathrm{t}^{-1}$ sugar. Therefore, trinexapac-ethyl had suppressive effect on the quality of juice, mostly regarding to the total soluble solids and yield of sugar. Plants sprayed with trinexapac-ethyl at $1.61 \mathrm{ha}^{-1}$ developed the most fibrous stalks, as host-defense system response to stress induced on plant physiology. The conclusion is, therefore, that although does prejudices the quality of juice, making it unsustainable to the production of first-generation ethanol, trinexapac-ethyl as chemical ripening agent could lead the sweet sorghum cv. CMSXS-646, while lignocellulose renewable source, to the industrialization of cellulosic ethanol and bioelectricity.

Keywords: plant growth regulator, plant physiology, phytorregulator, Sorghum bicolor (L.) Moench, technological quality.
\end{abstract}

\section{TRINEXAPAC-ETHYL COMO AGENTE QUÍMICO DE AMADURECIMENTO NO CULTIVO DE SORGO SACARINO}

\begin{abstract}
RESUMO - As referências literárias sobre a qualidade do suco da cultura do sorgo sacarino após a pulverização de agentes químicos de maturação são raramente encontradas, principalmente em relação ao trinexapac-etila. Nesse sentido, este artigo compartilha um conteúdo inédito sobre o amadurecimento fisiológico quimicamente induzido no sorgo sacarino cv. CMSXS-646 por pulverização de trinexapac-etilo antes da floração da cultura. Um pulverizador costal de $\mathrm{CO} 2$ pressurizado, com pontas de pulverização planas, foi empregado para pulverizar exogenamente o inibidor de crescimento de plantas a 0,4, 0,8 e 1,61 ha- 1 em plantas com 90 dias de idade. Logo após a colheita, amostras de suco e lignocelulose foram avaliadas tecnologicamente quanto a sólidos solúveis totais, sacarose, pureza, açúcares redutores, açúcares redutores totais, fibras e rendimento de açúcar. Plantas de sorgo sacarino expostas ao trinexapac-ethyl a 0,4 e 0,81 ha- 1 produziram sucos com aproximadamente 20,2 e $20,3^{\circ}$ Brix, 15,1 e $13,2 \%$ de sacarose, 74,6 e $64,9 \%$ de pureza, bem como 107,7 e 98,2 kg t-1 de açúcar., respectivamente. Diferentemente, plantas cultivadas como controle, sucos com $21,0^{\circ}$ Brix, $16,0 \%$ de sacarose, $76,9 \%$ de pureza e $118,0 \mathrm{~kg}$ t- 1 de açúcar. Portanto, o trinexapac-ethyl teve efeito supressor sobre a qualidade do suco, principalmente em relação ao total de sólidos solúveis e rendimento de açúcar. Plantas pulverizadas com trinexapac-ethyl a 1,6 1 ha-1 desenvolveram os colmos mais fibrosos, como resposta do sistema de defesa do hospedeiro ao estresse induzido na fisiologia das plantas. Conclui-se, portanto, que embora prejudique a qualidade do suco, tornando-o insustentável à produção de etanol de primeira geração, o trinexapac-ethyl como agente de amadurecimento químico pode levar o sorgo sacarino cv. CMSXS-646, enquanto fonte renovável de lignocelulose, para a industrialização do etanol celulósico e bioeletricidade.

Palavras-chave: regulador de crescimento vegetal, fisiologia vegetal, fitorregulador, Sorghum bicolor (L.) Moench, qualidade tecnológica.
\end{abstract}


Nowadays, Brazil accounts for the major world's producer of sugarcane-derived bioethanol, highlight also as reference on technology for commercially industrialization of white sugar and jaggery. Hence, sugarcane crop is currently the most relevant bioenergy whole-feedstock in the domestic sugar-energy sector. Most recently, however, sugar beet, corn, cassava and sweet sorghum crops have been largely cultivated by Brazilian's producers from Southeast, Midwest and Northeast, with intention to produce and then supply starch-rich raw materials to the production of yeasts-fermented liquid biofuels (Carpio \& Souza 2017; Sasaki et al., 2017; Brinckman et al., 2018).

The sweet sorghum crop (Sorghum bicolor L. Moench)is best-classified by experts on botany science as higher-grass specie into the Poaceae family. Under economic perspective, it is the fifth most important cereal crop worldwide. Furthermore, it qualifies also as bioenergy whole-feedstock to the production of first-generation ethanol, cellulosic ethanol and bioelectricity cogeneration from the lignocellulose burning down into large-capacity industrial boilers, mostly due to its juice quality and productivity of biomass. Also, sweet sorghum crop can produce grains, alcoholic beverages, forage, hydrolized silage, jaggery, syrup, paper, enzymatically-fermented lactic acid and hydrated alcohol; that is, it allows multipurposes (Chohnan et al., 2011; Brett et al., 2013; Rohowsky et al., 2013; Takaki et al., 2015; Barcelos et al., 2016; Ou et al., 2016).

The sweet sorghum crop is physiographically adapted to both tropical and subtropical climates, moderately resistant to the pests attack, drought, heat, water stress, low soil fertility and salinity, beyond to has shorter commercial cycle than sugarcane crop, ranging from 90 to 120-days. In Brazil, it has been a long time cultivated by non-capitalized farmers under marginal lands conditions, where the majoritary of the food crops can not perform very well, and most recently in sugarcane fields in renovation, as alternative to avoid mill plants standing idles over the sugarcane crop off-season (Wu et al., 2010; Viana et al., 2016; Sasaki et al., 2017; Thani et al., 2017).

Although does not requires great changes in existing infrastructure for the commercially production of sugarcane-derived first-gneration ethanol, sweet sorghum crop has shorter useful industrial period than sugarcane crop, making planning difficult. A way to improve it, therefore, is by the use of chemical ripening agents, known also as phytorregulators or plant growth regulators; that is, naturally occurring or synthetic compounds capable to affect developmental and metabolic processes in higher-plant species. In Brazil, sulfumeturon-methyl, ethephon, paraquat, glyphosate, fluazifop-p-butyl, thidiazuron and trinexapac-ethyl, among other synthetic substances have been tested as chemical ripening agents on sugarcane fields, aiming to improve productivity and quality in both sugar and bioethanol and, mostly, save the total cost of production by allowing mechanized harvesting to be performed as earliest as possible. Hence, literary references on the chemically-induced physiological ripening in sweet sorghum crop are rarely found up (Meschede et al., 2012; Brett et al., 2013; Rademacher, 2015; Barcelos et al., 2016).

As articles on plant growth regulation highlight, trinexapac-ethyl spraying on sweet sorghum crop can improve the quality of juice by supressing synthesis of phytohormones closely envolved in the plant growth, such as auxins and gibberellins. As result to better partitioning photoassimilates, larger yield of sugar and productivity of biomass can be gained by producers in shorter time. On the other hand, 
current scientific researches emphasize trinexapacethyl at lower doses can breakdown carotenoids and chlorophylls, that is, the most relevant photosynthetic pigments to the physiological ripening in both sweet sorghum and sugarcane crops (Inoue et al., 2015; Masson et al., 2015; Lozano et al., 2018).

From the aforementioned literary references, this study shares an unpublished technical content about chemically-induced physiological ripening on the sweet sorghum cv. CMSXS-646 by spraying trinexapac-ethyl before the crop flowering.

\section{Material and Methods}

\section{Study area}

The research was conducted in the experimental field of the São Paulo Agency for Research on Agribusiness Technology (APTA), located in the municipality of Andradina, São Paulo, Brazil, within the harvest season 2015/16. The regional climate qualifies as Aw, with rainy summer and dry winter, while the soil is sandy eutrophic Yellow-Red Latosol.

\section{Plant material}

The sweet sorghum cv. CMSXS-646 seeds were collected from Brazilian Agricultural Research Corporation (Eembrapa Milho e Sorgo) germoplasm collection, located in the municipality of Sete Lagoas, Minas Gerais, Brazil.

\section{Experimental design}

A experimental design in randomized blocks was performed, with four repilications for the plant growth inhibitor trinexapac-ethyl at 0.4, 0.8 and 1.61 ha $^{-1}$. Complementarily, sweet sorghum plants treated with water were cultivated as control.

\section{Chemical analysis of the soil, Crop sowing and Management}

On middle September, 2015, soil was chemically analyzed, in order to characterize it at 0.0 to $0.4 \mathrm{~m}$ depth: $5.6 \mathrm{pH}, 11.0 \mathrm{~g} \mathrm{dm}^{-3}$ organic matter, $2.5 \mathrm{mg} \mathrm{dm}^{-3}$ phosphorus, $2.6 \mathrm{mmol}_{\mathrm{c}} \mathrm{dm}^{-3}$ potash, 12.5 $\mathrm{mmol}_{\mathrm{c}} \mathrm{dm}^{-3}$ calcium, $7.0 \mathrm{mmol}_{\mathrm{c}} \mathrm{dm}^{-3}$ magnesium, 9.5 $\mathrm{mg} \mathrm{dm}{ }^{-3}$ sulphate, $19.0 \mathrm{mmol}_{\mathrm{c}} \mathrm{dm}^{-3}$ potential acidity, $0.1 \mathrm{mmol}_{\mathrm{c}} \mathrm{dm}^{-3}$ aluminum, $22.5 \mathrm{mmol}_{\mathrm{c}} \mathrm{dm}^{-3}$ sum of exchangeable cations, $41.5 \mathrm{mmol}_{\mathrm{c}} \mathrm{dm}^{-3}$ total cations exchange capacity, $54.0 \%$ saturation of exchangeable cations; $125.0 \mathrm{~g} \mathrm{~kg}^{-1}$ clay, $35.0 \mathrm{~g} \mathrm{~kg}^{-1}$ silt and $840.0 \mathrm{~g}$ $\mathrm{kg}^{-1}$ sand. On October, 2015, soil acidity and natural fertility were improved with $2.0 \mathrm{t} \mathrm{ha}^{-1}$ limestone and $0.5 \mathrm{t} \mathrm{ha}^{-1}$ NPK-fertilizer (04-14-08), respectively, as the recommendations of Raij et al. (1996). On December, 2015, fifteen sweet sorghum seeds were hand sowed into five $5 \mathrm{~m}$-length sowing rows, spaced at $0.5 \mathrm{~m}$. On beginning January, 2016, the less vigorous 20-days-old plants were hand thinned, with intention to guarantee $100.0 \mathrm{mil} \mathrm{ha}^{-1}$ population density, as the recommendations of Durães (2011). Over the experimentation, crop management was performed in agreement with literary recommendations on pests, mineral fertilizing and irrigation (Lozano et al., 2018).

\section{Trinexapac-ethyl spraying}

On March, 2016, trinexapac-ethyl was exogenously sprayed on 90-days-old sweet sorghum plants before the flowering, with a $2 \mathrm{~m}$-long $\mathrm{CO}_{2}$ pressurized backpack sprayer, with five flat spray nozzles 11002 spaced at $0.5 \mathrm{~m}$, working at 40.0 PSI 
and $200.01 \mathrm{ha}^{-1}$. The crop treatment was carried out in morning, at $27.5 \pm 2.5^{\circ} \mathrm{C}$ temperature and $60.5 \pm$ $5.5 \%$ air relative humidity (Correia \& Villela, 2015; Viana et al., 2016; Lozano et al., 2018).

\section{Crop harvesting and Assessment}

On beginning April, 2016, 110-days-old sweet sorghum plants were hand harvested into three central rows into each experimental plot. After the removing leaves, sweet sorghum stalks were milled trhough hydraulic press working at 25.0 Mpa pressure. Then, juice and lignocellulose samples were technologically assessed to total soluble solids, sucrose, purity, reducing sugars, total reducing sugars, fibers and yield of sugar, as the guidelines from the Council of Sugarcane, Sugar and Ethanol Producers of the State of São Paulo (Consecana, 2006).

\section{Data Analysis}

For the statistical analysis of the data set, the Fisher and regression tests were applied, using the software R Studio.

\section{Results and Discussion}

\section{Total soluble solids (SST), Sucrose (POL) and Purity}

\section{SST}

As presented in Figure 1, plants developed as control produced juices with 20.8 to $21.0{ }^{\circ}$ Brix, whereas plants exposured to the trinexapac-ethyl at 0.4 and $0.81 \mathrm{ha}^{-1}$, juices with the lowest SST contents, 19.9 to $20.5^{\circ}$ Brix and 19.8 to $20.5^{\circ}$ Brix, respectively.
On the other hand, plants sprayed with $1.61 \mathrm{ha}^{-1}$ produced juices with $20.9{ }^{\circ}$ Brix. From these results, therefore, the plant growth inhibitor trinexpac-ethyl at the highest dose qualified as more efficient to induce synthesis and accumulation of total soluble solids in sweet sorghum stalks than it at lower doses. Nevertheless, none dose tested significantly increased SST content in the sweet sorghum cv. CMSXS-646.

Lozano et al. (2018), who conducted the scientific study on the effects of flowering inhibitor agents on sweet sorghum crop, emphasize some hybrids exposured to the application of ethephon can produce juices with 16.6 to $19.0{ }^{\circ}$ Brix and, consequently, better-quality bioethanol. On the other hand, Pereira Filho et al. (2013), who performed the work on the sweet sorghum crop behavior under population densities to production of biofuel, prove varieties and elite-lines can supply juices with 14.3 to $23.1{ }^{\circ}$ Brix. Sweet sorghum crop physiological ripening is naturally governed by genotype, soil fertility, rainfall, temperature, solar radiation and photoperiod (Crusciol et al., 2017). Thus, others biotic and abiotic agents in addition to plant growth regulators affecting soluble solids, mostly regarding to the fermentable sugars.

Viana et al. (2016), who performed the study on the morpho-anatomical and technological aspects of sweet sorghum crop, report cultivars BRS508 and BRS509 exposured to the trinexapac-ethyl at 0.2, 0.4 and $0.81 \mathrm{ha}^{-1}$ can produce juices with $10.8,9.7$ and $13.6{ }^{\circ}$ Brix, respectively, whereas plants cultivated as control, juices with $10.5^{\circ}$ Brix. Like Viana et al. (2015) also tested trinexapac-ethyl at 0.2, 0.4 and 0.8 $1 \mathrm{ha}^{-1}$ on the sweet sorghum cv. Biomatrix 535, found up however juices with larger SST contents, 16.74, 16.27 and $16.97^{\circ}$ Brix, respectively. In fact, genotype can significantly affect sweet sorghum crop response 

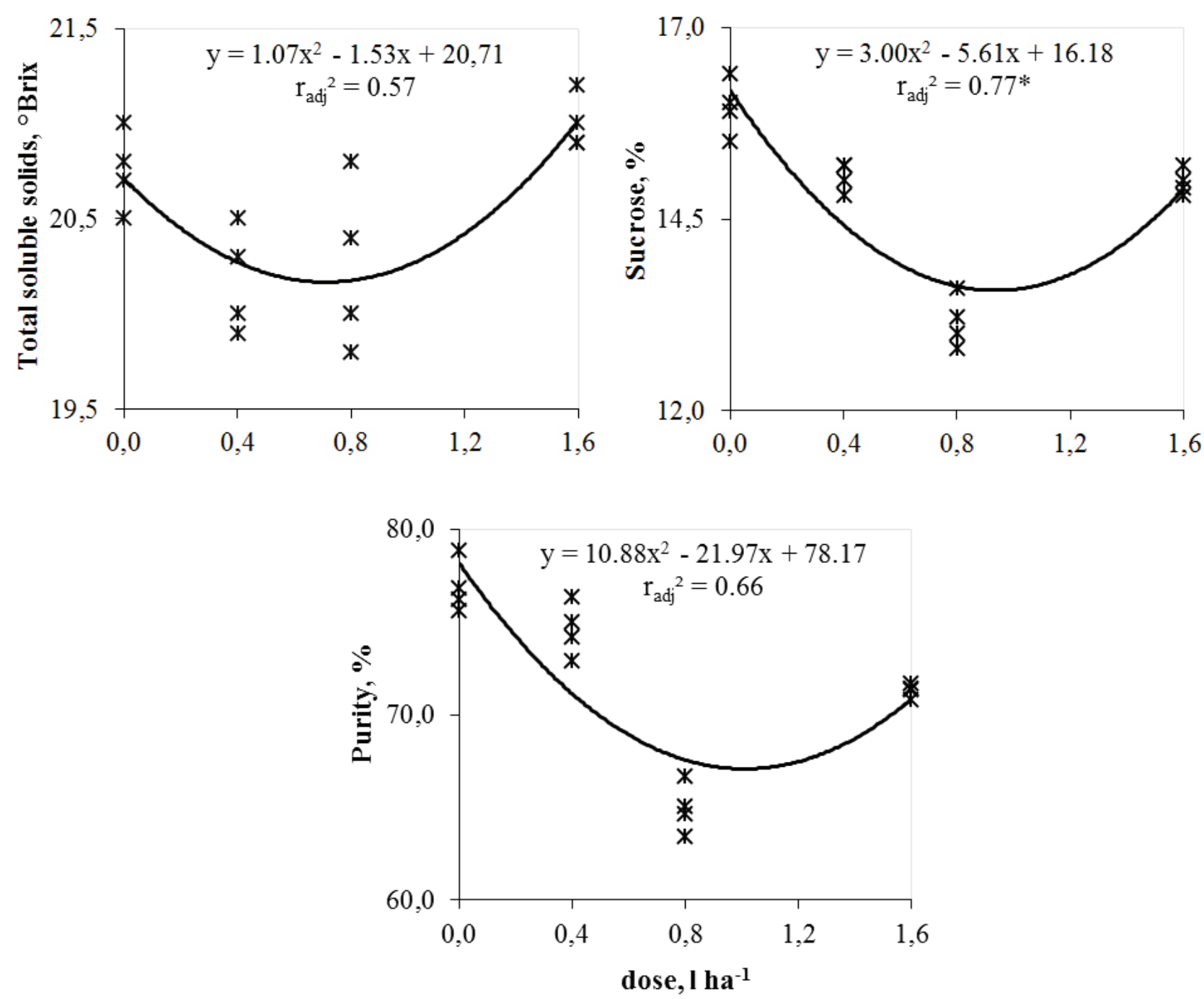

Figure 1 Non-linear effect of the plant growth inhibitor trinexapac-ethyl on total soluble solids, sucrose and purity in the sweet sorghum cv. CMSXS-646;

*Significant by the Fisher test at 0.05 probability.

to the ethyl-trinexapac. Like this study, literary references record also non-linear effect of trinexapacethyl on SST content in sweet sorghum crop.

In sugar-energy sector, harvesting is only performed when sugarcane plants qualify as physiologically capable to produce juice with 15.5 to $16.5{ }^{\circ}$ Brix (Inoue et al., 2015). Nevertheless, Viana et al. (2015) describe $18.0^{\circ}$ Brix as ideal SST content to the sugarcane mechanized harvesting, due to larger useful industrial period, better quality of yeastsperformed alcoholic fermenting and, consequently, larger producitivty of ethanol. Despite negative effect of trinexapac-ethyl on SST content, reducing it, sweet sorghum cv. CMSXS-646, both with and without presence of the plant growth inhibitor, produced juice with SST content larger than the critical limit required 
to sugarcane harvesting and milling.

The study on the total soluble solids and fermentable sugars in Sorghum spp, authored by Kawahigashi et al. (2013), reports 75\% sucrose in juices ghatered from varieties with SST content larger than $15.0{ }^{\circ}$ Brix. Accordingly, juice derived from the sweet sorghum cv. CMSXS-646 should contain satisfactory level of fermentable sugars, organic substrate essential to the production of firstgeneration ethanol in a commercial-scale (Takaki et al., 2015). In fact, SST is one of the most relevant technological quality indicatives in sweet sorghum crop, since it significantly correlates with POL and yield of sugar. In sugar-energy sector, it has been used like a criteria to efficiently apart amounts of sucrose for the concurrently industrialization of white sugar or jaggery and ethanol (Viana et al., 2016; Kawahigashi et al., 2013; Oliveira et al., 2016).

\section{POL}

A negative relation between POL and dose was also noted, since plants sprayed with water produced juices with 15.5 to $16.4 \%$ sucrose, whereas plants exposured to the trinexapac-ethyl at $0.4,0.8$ and 1.61 $\mathrm{ha}^{-1}$, juices with lower sucrose contents, with 14.8 to $15.2,12.8$ to 13.6 , and 14.8 to $15.2 \%$, respectively. Therefore, trinexapac-ethyl at the highest dose presented also as more efficient to induce synthesis and accumulation of sucrose in the sweet sorghum cv. CMSXS-646 than it at lower doses.

Like this study, Viana et al. (2016) found up also non-linear effect of trinexapac-ethyl on POL in juices dervived from the sweet sorghum cultivars BRS508 and BRS509, which produced 3.4, 3.3 and $4.4 \%$ sucrose in presence of the plant growth inhibitor at $0.2,0.4$ and $0.81 \mathrm{ha}^{-1}$, respectively, however $3.2 \%$ sucrose in absence it. Similar behavior was also noted by Viana et al. (2015), who recorded 6.9, 7.4 and $7.7 \%$ sucrose in the sweet sorghum cv. Biomatrix 535 exposured to the trinexapac-ethyl at same doses, respectively. From these literary reference, therefore, non-linear relation between POL and dose is commonly noted for sweet sorghum cultivars chemically treated with trinexapac-ethyl.

In sugarcane crop, synthesis of sucrose is enzymatically governed by soluble acid invertases, alkaline invertases, sucrose phosphate synthase and sucrose synthase. In particular, soluble acid invertases can hydrolize sucrose, producing fermentable monosaccharides. As result, sucrose content decreases, while the fructose and glucose contents increases, significantly. Unlike, alkaline invertases can avoid sucrose to be xylematically translocated from stalks to leaves or any other reproductive strucutres, such as panicle and grains in sweet sorghum crop, while preserving much fermentable polysaccharides content as possible into stalks (Chandra et al., 2012; Leite et al., 2015).

The scientific research on the activities of enzymes closely envolved in synsthesis of sucrose in popular sugarcane varieties, authored by Crusciol et al. (2017), shows positive and significant correlations between specifical enzymatic activities of alkaline invertases, sucrose phosphate synthase and sucrose synthase and POL, as well negative correlation between acid invertases activity and POL. Another article, authored by Chandra et al. (2012), emphasizes trinexapac-ethyl can significantly reduce acid inverstases activity in sugarcane plants in beginning development. In addition to plant growth regulators, rainfall, temperature, soil moisture and photoperiod can also change alkaline invertases activity (Crusciol et al., 2017). 
From the aforementioned literary references, together with results this study, trinexapac-ethyl tested as plant growth regulator at lower doses may induce acid invertases activity in the sweet sorghum cv. CMSXS-646, resulting in significant decreasing in sucrose content by promoting synthesis of fructose and glucose in excess, whereas it at higher doses may synergistically enhance the enzymatic activies of alkaline invertases, sucrose phosphate and sucrose synthase, efficiently promoting synthesis and then larger accumulation of sucrose in juice. Accordingly, the scientific research, authored by Leite et al. (2015), shows broad-spectrum herbicide glyphosate at lower doses can inhibit acid inverstases in sugarcane plants, resulting in larger accumulation of sucrose in whole stalk, including in internodes.

As reported by Oliveira Filho et al. (2016), ethephon, sulfumeturon-methyl, $\mathrm{KNO}_{3}$ and trinexapac-ethyl can suppress growth and development in both sweet sorghum and sugarcane crops by chemically inhibiting synthesis of auxins and gibberellins. As result, plants does not flowering and then photoassimilates are strongly translocated from leaves to stalks, increasing sucrose and total soluble solids contents in juice. As seen, plant growth regulators can perform very well as chemical ripening agents in sweet sorghum crop, improving its quality of juice, in disagreement with results this study.

In sugar-energy sector, POL is so many important to quality of juice as SST, since it allows accurated estimation on amount of sucrose, polysaccharide essential to yeasts-performed firstgeneration ethanol fermenting (Wu et al., 2010; Thani et al., 2017). In Brazil, nowadays, sugarcane crops harvesting is performed when plants produce juice with more than $14.0 \%$ sucrose; otherwise, shorter useful industrial period and lower productivity of bioethanol happen (Inoue et al., 2015). Thus, sweet sorghum cv. CMSXS-646, without presence of trinexapac-ethyl, could be useful while raw material for the production of first-generation ethanol, since it can produce juice with approximately two points of sucrose above to the critical limit required to sugarcane harvesting and milling.

\section{Purity}

Sweet sorghum plants sprayed with trinexapacethyl at $0.4,0.8$ and $1.61 \mathrm{ha}^{-1}$ produced juices lesser pure than plants cultivated as control, whose purity in juice ranged from 75.6 to $78.8 \%$, approximately. Such behavior was expected, since SST and POL were also negatively influenced by the plant growth inhibitor. Therefore, trinexapac-ethyl qualified as chemical ripening agent very prejudicial to the technological quality of juice derived from the sweet sorghum cv. CMSXS-646.

Like this study, Viana et al. (2016) found up also non-linear effect of trinexapac-ethyl on purity in juices derived from the sweet sorghum cultivars BRS508 and BRS509, which presented 34.3\% purity, in absence of the chemical ripening agent, but $33.6 \%$ purity, in presence of trinexapac-ethyl at $0.81 \mathrm{ha}^{-1}$. On the other hand, Viana et al. (2015) found up the largest purity contents in juice collected from the sweet sorghum cv. Biomatrix 535 exposured to the trinexapac-ethyl at 0.4 and $0.81 \mathrm{ha}^{-1}$.

Purity is understood also as one of the most relevant indicatives of technological quality of juice in sweet sorghum crop, being indirectly calculated by POL to SST ratio. Other physical, chemical and biological factors in addition to sucrose and soluble solids can change it, significantly; mineral elements, soil colloidal particles and plant materials 
are examples. In sugar-energy sector, raw materials ideal to the commercially production of ethanol must present more than $70.0 \%$ purity; otherwise, they are unqualified to such purpose (Oliveira Filho et al., 2016). Therefore, sweet sorghum cv. CMSXS-646, without presence of trinexapac-ethyl, has great potential as bioenergy feedstock to the industrialization of biofuels, since it can produce juice with purity above to the critical limit requiried by mill plants and distilleries.

\section{Reducing sugars (AR), Total reducing sugars (ART), Fibers and Yield of sugar}

\section{AR}

As presented in Figure 2, plants treated with trinexapac-ethyl at $0.4,0.8$ and $1.61 \mathrm{ha}^{-1}$ produced juices with 1.1 to $1.4,1.2$ to 1.4 , and 1.2 to $1.6 \%$ reducing sugars, respectively, whereas plants cultivated as control, juices with 0.9 to $1.2 \%$ reducing sugars. In fact, trinexapac-ethyl at lowest doses presented more efficient to promote synthesis of fructose and sucrose in the sweet sorghum cv. CMSXS-646 than it at the highest dose, probably due to its synergistic relation with acid invertases.

Like this study, Kawahigashi et al. (2013) also reported negative relations between SST, POL and AR. Sucrose, glucose and fructose occur in higher levels in juices derived from sugarcane and sweet sorghum crops (Takaki et al., 2015). In commercially production of first-generation ethanol, feedstock with AR content in excess can reduce yield and quality of biofuel, due to shorter availability of sucrose (Chohnan et al., 2011; Rohowsky et al., 2013). Accordingly, juice derived from the sweet sorghum cv. CMSXS-646, without presence of trinexapac- ethyl, could perform very well as bioenergy feedstock in the industrialization of anydrous alcohol, due to its lower AR content.

\section{ART}

Sweet sorghum plants treated with trinexapacethyl at 0.4 and $0.81 \mathrm{ha}^{-1}$ produced juices with 12.0 to 12.1 and 10.9 to $11.5 \%$ total reducing sugars, whereas plants cultivated as control and sprayed with trinexapac-ethyl at $1.61 \mathrm{ha}^{-1}$, juices with 13.0 to 13.4 and 12.9 to $13.4 \%$ total reducing sugars, respectively. Unlike sugarcane crop, in which POL and SST are more relevant than any other indicatives of technological quality of juice, ART is the main indicative of quality of juice in sweet sorghum crop, because it allows accurated estimation on yield of sugar (Takaki et al., 2015).

\section{Fibers}

Sweet sorghum plants treated with trinexapacethyl at $0.4,0.8$ and $1.61 \mathrm{ha}^{-1}$ produced stalks with 19.8 to $20.2,19.8$ to 20.4 and 20.8 to $21.3 \%$ fibers, respectively, whereas plants cultivated as control developed the less fibrous stalks, with 18.2 to $18.6 \%$ fibers. Therefore, the plant growth inhibitor had positive effect on fibers content in the sweet sorghum cv. CMSXS-646. The scientific researches, conducted by Viana et al. (2015, 2016), show 13.2, 14.6 and $13.5 \%$ fibers in stalks ghatered from the sweet sorghum cultivars BRS508 and BRS509 exposured to the trinexapac-ethyl at $0.2,0.4$ and $0.81 \mathrm{ha}^{-1}$, as well as $15.3,14.9$ and $14.6 \%$ fibers in stalks collected from the cultivar Biomatrix 535 sprayed with the chemical ripening agent at same doses, respectively. From these literary references, together with results this 

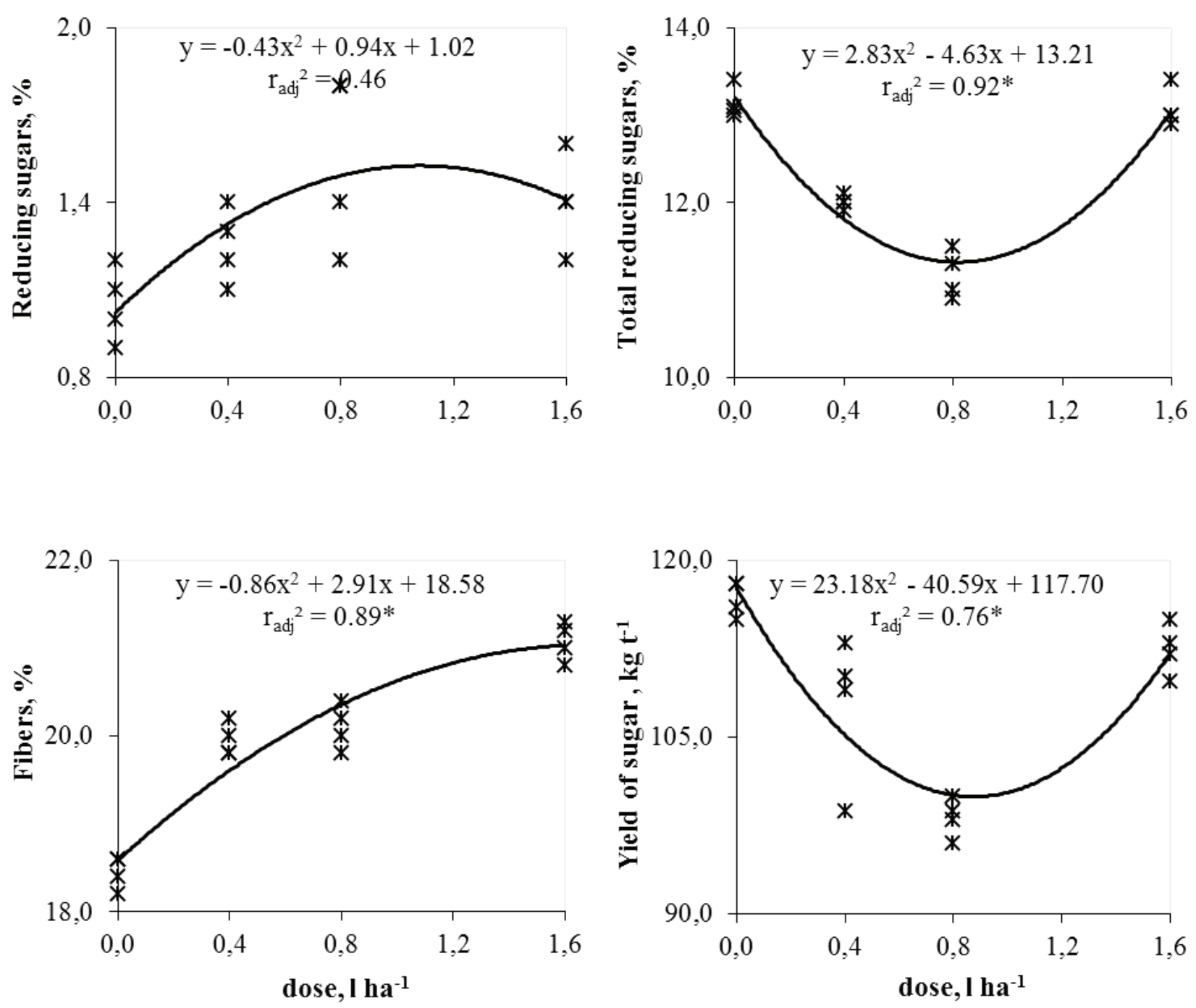

Figure 2 Non-linear effect of the plant growth inhibitor trinexapac-ethyl on reducing sugars, total reducing sugars, fibers and yield of sugars in the sweet sorghum cv. CMSXS-646;

*Significant by the Fisher test at 0.05 probability.

study, sweet sorghum crop under effect of trinexapacethyl commonly produces fibrous stalks.

The scientific research on the metabolic changes induced on sugarcane crop by spraying plant growth regulators, conducted by Meschede et al. (2012), describes glyphosate can also lead sugarcane plants to develop fibrous stalks, probably due to chemical stress affecting plant physiology. In host- defense system, fibers play key role as mechanical barriers, preventing crops from stressfully natural and synthetic agents. Under field conditions, fibrous sugarcane plants usually present as more resistant to stressing agents, such pests and diseases, heat and drought, beyond to allow more cuts than less fibrous plants. For instance, energy-cane allows from eight to ten harvesting in sequence, whereas sugarcane 
commercial varieties, from four to five harvesting (Kim \& Day, 2011).

In sugar-energy sector, raw material with more than $12.5 \%$ fibers qualifies as very prejudicial to the industrialization of first-generatiom ethanol (Viana et al., 2016). However, it can be useful in bioelectricity cogeneration from the lignocellulose burning down into large-capacity industrial boilers, due to positive relation between fibers and gross calorific value. Therefore, sweet sorghum cv. CMSXS-646 could perform very well while bionergy whole-feedstock in the production of cellulosic ethanol and bioelectricity, mostly in presence of trinexapac-ethyl at 0.8 and 1.6 $1 \mathrm{ha}^{-1}$, due to the largest glucose and fibers contents. Also, trinexapac-ethyl could be useful as chemical ripening agent in sweet sorghum crops focused to produce and supply lignocellulosic raw material to the industrialization of biomass-to-liquid biofuels (Matsuoka et al., 2014).

\section{Yield of sugar}

Sweet sorghum plants treated with trinexapacethyl at 0.4 and $0.81 \mathrm{ha}^{-1}$ produced 98.7 to 113.0 and 96.0 to $100.0 \mathrm{~kg} \mathrm{t}^{-1}$ sugar, respectively, whereas plants cultivated as control and sprayed with the plant growth inhibitor at 1.61 ha $^{-1}, 115.0$ to 118.0 and 109.7 to 115.0 $\mathrm{kg} \mathrm{t}^{-1}$ sugar, respectively. From these results, therefore, trinexapac-ethyl had also negative effect on yield of sugar in the sweet sorghum cv. CMSXS-646. Such behavior can be assigned to the decreases induced by trinexapac-ethyl in SST, POL and ART, indicatives significantly contributing to the yield of sugar.

In absence and presence of trinexapac-ethyl at $0.2,0.4$ and $0.81 \mathrm{ha}^{-1}$, sweet sorghum cultivars BRS508 and BRS509 can produce about 46.5, $28.3,43.9$ and $57.6 \mathrm{~kg} \mathrm{t}^{-1}$ sugar, respectively, while the sweet sorghum cv. Biomatrix 535 at same conditions, 68.3, 77.7, 81.4 and $83.3 \mathrm{~kg} \mathrm{t}^{-1}$ sugars, respectively (Viana et al., 2015, 2016). The short communication, authored by McKinley et al. (2016), reports saccharine sorghum species can produce 80.0 to $127.0 \mathrm{~kg} \mathrm{t}^{-1}$ sugar, proving in addition to chemical ripening agents, genotype qualifies also as factor influencing to the yield of sugar. From these literary references, therefore, sweet sorghum cv. CMSXS-646 has great potential as bioenergy crop to the sugar-energy sector.

\section{Conclusion}

The conclusion is, therefore, that although does prejudices the technological quality of juice, making it unsustainable to the commercially production of first-generation ethanol, trinexapac-ethyl as plant growth regulator could lead the sweet sorghum cv. CMSXS-646, while lignocellulose renewable source, to the industrialization of cellulosic ethanol, biomassto-liquid biofuels and bioelectricity.

\section{References}

BARCELOS, C. A.; MAEDA, R. N.; SANTA ANNA, L. M. M.; PEREIRA JR., N. Sweet sorghum as whole-crop feedstock for ethanol production. Biomass and Bioenergy, v. 94, p. $46-56,2016$.

DOI: 10.1016/j.biombioe.2016.08.012.

BRETT, A.; GILLIAN, E.; RANDALL, P. Pilot plant clarification of sweet sorghum juice and evaporation of raw material and clarified juices. Industrial Crops and Products, v. 49, p. 648- 658, 2013.

DOI: $10.1016 /$ j.indcrop.2013.06.027.

BRINCKMAN, M. L. J.; CUNHA, M. P.; HEIJNEN, S.; WICKE, B.; GUILHOTO, J. J. M.; WALTER, A.; FAAIJ, A. P. C.; HILST, F. Interregional assessment of socio- 
economic effects of sugarcane ethanol production in Brazil. Renewable Sustainable Energy Reviews, v. 88, p. 347-362, 2018.

DOI: 10.1016/j.rser.2018.02.014.

CARPIO, L. G. T.; SOUZA, F. S. Optimal allocation of sugarcane bagasse for producing bioelectricity and second generation ethanol in Brazil: scenarios of cost reductions.

Renewable Energy, v. 111, p. 771-780, 2017.

DOI: 10.1016/j.renene.2017.05.015.

CHANDRA, A.; JAIN, R.; SOLOMON, S. Complexities of invertases controlling sucrose accumulation and retention in sugarcane. Current Science Association, v. 102, n. 6, p. 857-866, 2012.

CHOHNAN, S.; NAKANE, M.; RAHMAN, M. H.; NITTA, Y.; YOSHIURA, T.; OHTA, T.; KURUSU, H. Fuel ethanol production from sweet sorghum using repeated-batch fermentation. Journal of Bioscience and Bioengineering, v. 111, n. 4, p. 433-436, 2011.

DOI: 10.1016/j.jbiosc.2010.12.014.

CONSECANA. Conselho dos Produtores de Cana de Açúcar, Açúcar e Etanol do Estado de São Paulo. Manual de instruções. São Paulo, 2006.

CORREIA, N. M.; VILLELA. G. B. Trinexapac-ethyl and sulfumeturon-methyl selectivity to young eucalyptus plants. Planta Daninha, v. 33, n. 2, p. 259-266, 2015. DOI: $10.1590 / 0100-83582015000200011$.

CRUSCIOL, C. A. C.; LEITE, G. H. P. G. F.; SIQUEIRA, G. F.; SILVA, M. A. Response of application of growth inhibitors on sugarcane productivity and sucrose accumulation in the middle of cropping season in Brazil. Sugar Tech, v. 19, n. 2, p. 155-164, 2017.

DOI: $10.1007 / \mathrm{s} 12355-016-0450-1$.

DURÃES, F. O. M. Sorgo sacarino: desenvolvimento de tecnologia agronômica. Agroenergia em Revista, ano 2, n. 3, p. 7, ago. 2011.

INOUE, M. H.; CAPPELLESSO, E. J. S.; MENDES, K. F.; BEM, R.; CONCIANI, P. A. Eficiência do bispyribac- sodium como maturador na cultura da cana-de-açúcar. Revista Ciência Agronômica, v. 46, n. 1, p. 80-88, 2015. DOI: $10.1590 /$ S1806-66902015000100010.

KAWAHIGASHI, H.; KASUGA, S.; OKUIZUMI, H.; HIRADATE, S.; YONEMARU, J. Evaluation of brix and sugar content in stem juice from sorghum varieties. Grass Science, v. 59, n. 1, p. 11-19, 2013.

DOI: $10.1111 /$ grs. 12006.

KIM, M.; DAY, D. Composition of sugar cane, energy cane, and sweet sorghum suitable for ethanol production at Louisiana sugar mills. Journal of Industrial Microbiology \& Biotechnology, v. 38, n. 7, p. 803-807, 2011. DOI: $10.1007 / \mathrm{s} 10295-010-0812-8$.

LEITE, G. H. P.; ALEXANDRE, C.; CRUSCIOL, C.; SIQUEIRA, G. F. D.; SILVA, M. D. A. Plant regulators and invertase activity in sugarcane at the beginning of the harvest season. Ciência Rural, v. 45, n. 10, p. 1788-1794, 2015. DOI: $10.1590 / 0103-8478$ cr20141363.

LOZANO, E. V.; BLANCO, L. M.; ALCANTARA, G. U.; NOGUEIRA, L. C.; CIARAMELLO, S.; COSTA, G. H. G. Effect of application of flowering inhibitor on sweet sorghum. African Journal of Agricultural Research, v. 13, n. 4, p. 196-201, 2018. DOI: 10.5897/AJAR2017.12902.

MASSON, I. S.; COSTA, G. H. G.; ROVIERO, J. P.; FREITA, L. A.; MUTTON, M. A.; MUTTON, M. J. R. Produção de bioetanol a partir da fermentação de caldo de sorgo sacarino e cana-de-açúcar. Ciência Rural, v. 45, n. 9, p. 1695-1700, 2015. DOI: 10.1590/0103-8478cr20130549.

MATSUOKA, S.; KENNEDY, A. J.; SANTOS, E. G. D. D.; TOMAZELA, A. L.; RUBIO, L. C. S. Energy cane: its concept, development, characteristics, and prospects. Advances in Botany, v. 2014, p. 1-13, 2014. Article ID 597275.

DOI: $10.1155 / 2014 / 597275$.

MCKINLEY, B.; ROONEY, W.; WILKERSON, C.; MULLET, J. Dynamics of biomass partitioning, stem gene expression, cell wall biosynthesis, and sucrose 
accumulation during development of Sorghum bicolor. Plant Journal, v. 88, n. 4, p. 662-680, 2016.

DOI: $10.1111 /$ tpj.13269.

MESCHEDE, D. K.; VELINI, E. D.; TONIN, F. G.; CARBONARI, C. A. Alterações no metabolismo da canade-açúcar em função da aplicação de maturadores. Planta Daninha, v. 30, n. 1, p. 113-119, 2012.

DOI: $10.1590 / \mathrm{S} 0100-83582012000100013$.

OLIVEIRA FILHO, P. B.; DUARTE JÚNIOR, J. B.; COSTA, A. C. T.; OLIVEIRA, P. S. R.; MACEDO JÚNIOR, E. K. M.; GUIMARÃES, V. F.; BOSQUETTE, W. Chemical ripeners and different harvest periods in sugarcane in State of Paraná, southern Brazil. African Journal of Agricultural Research, v. 11, n. 39, p. $3904-$ 3913, 2016.

DOI: 10.5897/AJAR2014.9142.

OLIVEIRA, A. R. de; BRAGA, M. B.; SIMOES, W. L.; WALKER, A. M. Influência de lâminas de irrigação nas características tecnológicas de cana-de-açúcar. Petrolina: Embrapa Semiárido, 2016. 22 p. (Embrapa Semiárido. Boletim de Pesquisa e Desenvolvimento, 127).

OU, M. S.; AWASTHI, D.; NIEVES, I.; WANG, L.; ERICKSON, J.; VERMERRIS, W.; SHANMUGAM, K. T. Sweet sorghum juice and bagasse as feedstocks for the production of optically pure lactic acid by native and engineered Bacillus coagulans strains. Bioenergy Research, v. 9, n. 1, p. 123-131, 2016.

DOI: $10.1007 / \mathrm{s} 12155-015-9670-6$.

PEREIRA FILHO, A.; PARRELA, R. A. C.; MOREIRA, J. A. A.; MAY, A.; SOUZA, V. F.; CRUZ, J. C. Avaliação de cultivares de sorgo sacarino [Sorghum bicolor (L.) Moench] em diferentes densidades de semeadura visando a características importantes na produção de etanol. Revista Brasileira de Milho e Sorgo, v. 12, n. 2, p. 118-127, 2013. DOI: 10.18512/1980-6477/rbms.v12n2p118-127.

RADEMACHER, W. Plant growth regulators: backgrounds and uses in plant production. Journal of Plant Growth Regulation, v. 34, n. 4, p. 845-872, 2015.

DOI: $10.1007 / \mathrm{s} 00344-015-9541-6$.
RAIJ, B. van; CANTARELLA, H.; QUAGGIO, J. A.; FURLANI, A. M. C. (Ed.). Recomendacoes de adubação e calagem para o Estado de São Paulo. 2. ed. Campinas: Instituto Agronômico, 1996. 285 p. (IAC. Boletim Técnico, 100).

ROHOWSKY, B.; HABLER, T.; GLADIS, A.; REMMELE, E.; SCHIEDER, D. Feasibility of simultaneously saccharification and juice co-fermentation on hydrothermal pretreated sweet bagasse for ethanol production. Applied Energy, v. 102, p. 211-219, 2013.

DOI: 10.1016/j.apenergy.2012.03.039.

SASAKI, K.; TSUGE, Y.; KAWAGUCHI, H.; YASUKAWA, M.; SASAKI, D.; SAZUKA, T.; KAMIO, E.; OGINO, C.; MATSUYAMA, H.; JAND, H.; KONDO, A. Sucrose purification and repeated ethanol production from sugars remaining in sweet sorghum juice subjected to a membrane separation process. Applied Microbiology and Biotechnology, v. 101, n. 15, p. 6007-6014, 2017.

DOI: $10.1007 / \mathrm{s} 00253-017-8316-3$.

TAKAKI, M.; TAN, L.; MURAKAMI, T.; TANG, Y.; SUN, Z. Production of biofuels from sweet sorghum juice via ethanol-methane two-stage fermentation. Industrial Crops and Products, v. 63, p. 329-336, 2015.

DOI: $10.1016 /$ j.indcrop.2014.10.009.

THANI, A.; LAOPAIBOON, P.; LAOPAIBOON, L. Improvement of a continuous ethanol fermentation from sweet sorghum stem juice using a cell recycling system. Journal of Biotechnology, v. 251, p. 21-29, 2017.

DOI: 10.1016/j.jbiotec.2017.03.030.

VIANA, R. S.; FIGUEIREDO, P. A. M.; LISBOA, L. A. M.; ASSUMPÇÃO, A. C. N. D.; SÁ, M. E.; MAY, A. Aplicação de fitorreguladores químicos na qualidade tecnológica do sorgo sacarino cv. Biomatrix 535. Revista Brasileira de Milho e Sorgo, v. 14, n. 3, p. 326-334, 2015. DOI: 10.18512/1980-6477/rbms.v14n3p326-334.

VIANA, R. S.; FIGUEIREDO, P. A. M.; LISBOA, L. A. M.; MAGALHÃES, A. C. Morpho-anatomical aspects and technology quality of saccharine sorghum submitted to 
plant regulators. Revista Brasileira de Herbicidas, v. 15, n. 2, p. 175-183, 2016.

DOI: $10.7824 /$ rbh.v15i2.459.

WU, X.; STAGGENBORG, S.; PROPHETER, J. L.; ROONEY, W. L.; YU, J.; WANG, D. Features of sweet sorghum juice and their performance in ethanol fermentation. Industrial Crops and Products, v. 31, n. 1, p. 164-170, 2010. DOI: 10.1016/j.indcrop.2009.10.006. 